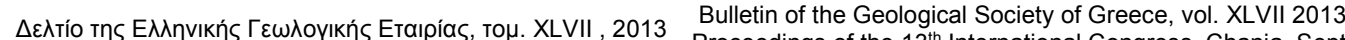
Практіка́ $13^{\text {ou }}$

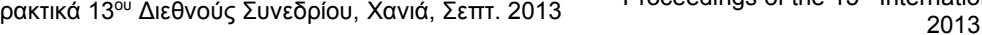

\title{
MATURITY OF DISPERSED ORGANIC MATTER IN BITUMINOUS FORMATIONS OF THE IONIAN ZONE (EPIRUS REGION, NW GREECE)
}

\author{
Rallakis D., Siavalas G., Oskay R.G., Tsimiklis D. and Christanis K. \\ University of Patras, Dept. of Geology,265.04 Rio-Patras,Greece, rallakis@upatras.gr, \\ christan@upatras.gr
}

\begin{abstract}
The main objective of this paper is to study by means of Organic Petrology techniques, the maturity of the dispersed organic matter from certain sedimentary formations of the Ionian Zone, such as the Bituminous Shale, the Upper Siliceous Vigla Formation and the Bituminous Sandstone. The samples were collected from outcropping sites located in the region of Epirus. Initially they were treated with acids $(\mathrm{HCl}-\mathrm{HF})$ to remove most of the carbonate and silicate minerals. Then a $\mathrm{ZnCl}_{2}$ solution was used to concentrate the organic-rich fraction. Total Organic Carbon (TOC) content was determined applying dichromate oxidation. Polished blocks were prepared from the concentrated organic matter mounted in epoxy resin and examined under the coal-petrography microscope. Emphasis was given to maceral identification and vitrinite reflectance $(R)$ measurements, which provide information regarding the quality and the maturity of the organic matter respectively, with implications for the petroleum generation potential regardless the level of alteration. The TOC and $R r$ values $(4.74 \%$ and $0.68 \%$, respectively) confirm to the oil potential of the Lower Jurassic Posidonia Shale. Nevertheless, it is suggested that detailed and higher resolution sampling focusing on the Lower Posidonia Shale, as well as organic petrography analyses coupled with Rock-Eval pyrolysis should be carried out in order to accurately determine its quality as petroleum source rocks.
\end{abstract}

Key words: Posidonia Shale, Organic Petrology, vitrinite reflectance.

\section{Пєрí $\eta \psi \eta$}

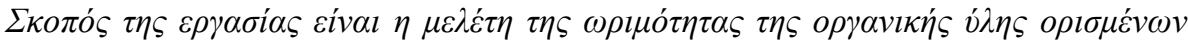

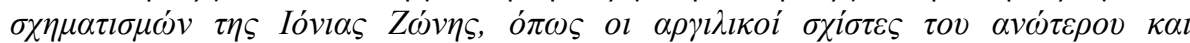

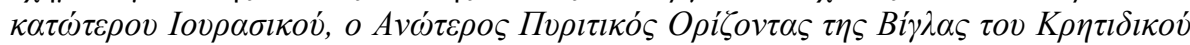

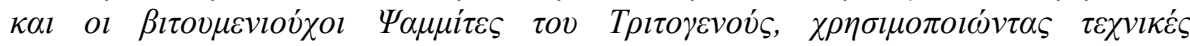

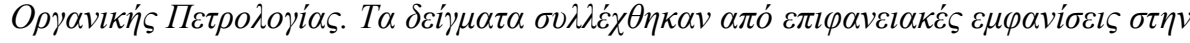

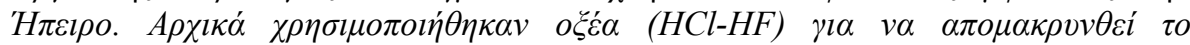

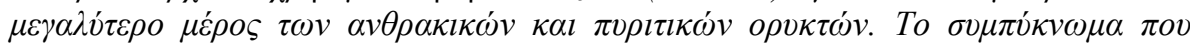

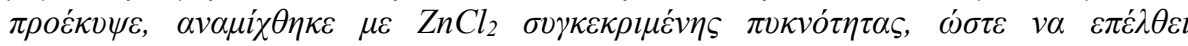

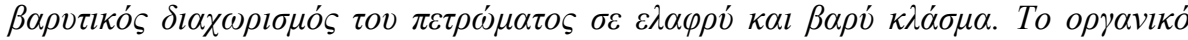

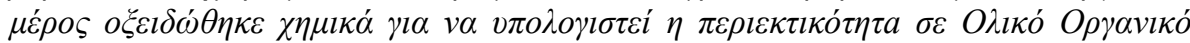

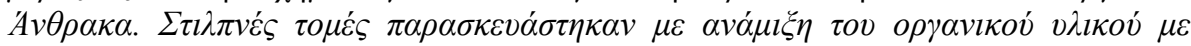

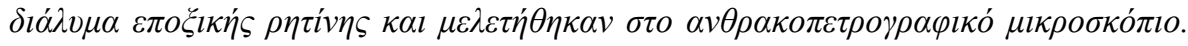

XLVII, No $2-880$ 


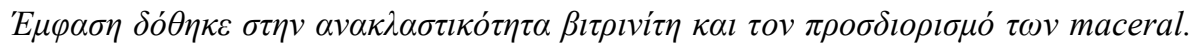

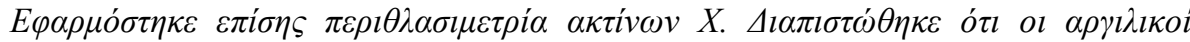

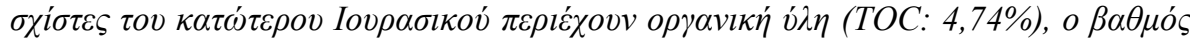

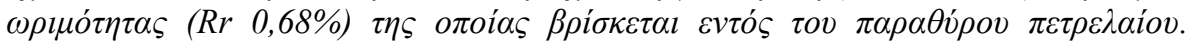

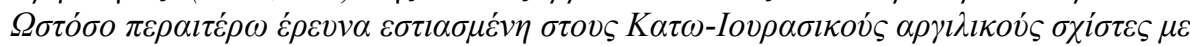

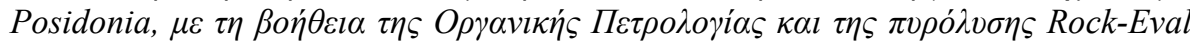

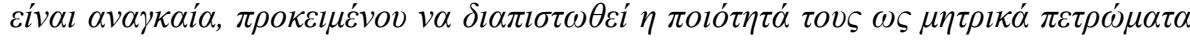

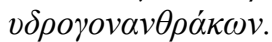

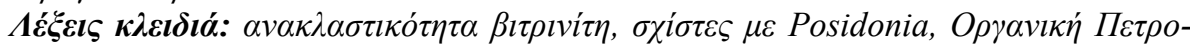

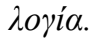

\section{Introduction}

The Ionian geotectonic zone (Figure 1) occupies the western part of Greece; the NW part of the zone has been studied over the last forty years in search for hydrocarbons (e.g. IGRS-IFP, 1966; BP, 1971; Jenkins, 1972; Karakitsios and Rigakis, 1996; 2007; Rigakis and Karakitsios, 1998; Avramidis and Zelilidis, 2001; Avramidis et al., 2002; Karakitsios, 2003; Zelilidis et al., 2003; Kokkinou et al., 2005).

According to Karakitsios and Rigakis (1996) the organic-rich facies of the Ionian Zone are: the shale of the Triassic breccias that have entered the gas window with a TOC value up to $11.15 \%$ and a petroleum potential of $74.02 \mathrm{mg} \mathrm{HC} / \mathrm{g}$ of rock; the Lower and Upper Posidonia Beds (or shale) with TOC content from 1.05-9.82\% and type I and II organic matter that is highly oil-prone; and the Vigla shale with TOC values from $1.44 \%$ to $2.44 \%$ and type I, II organic matter being at an early stage of maturation.

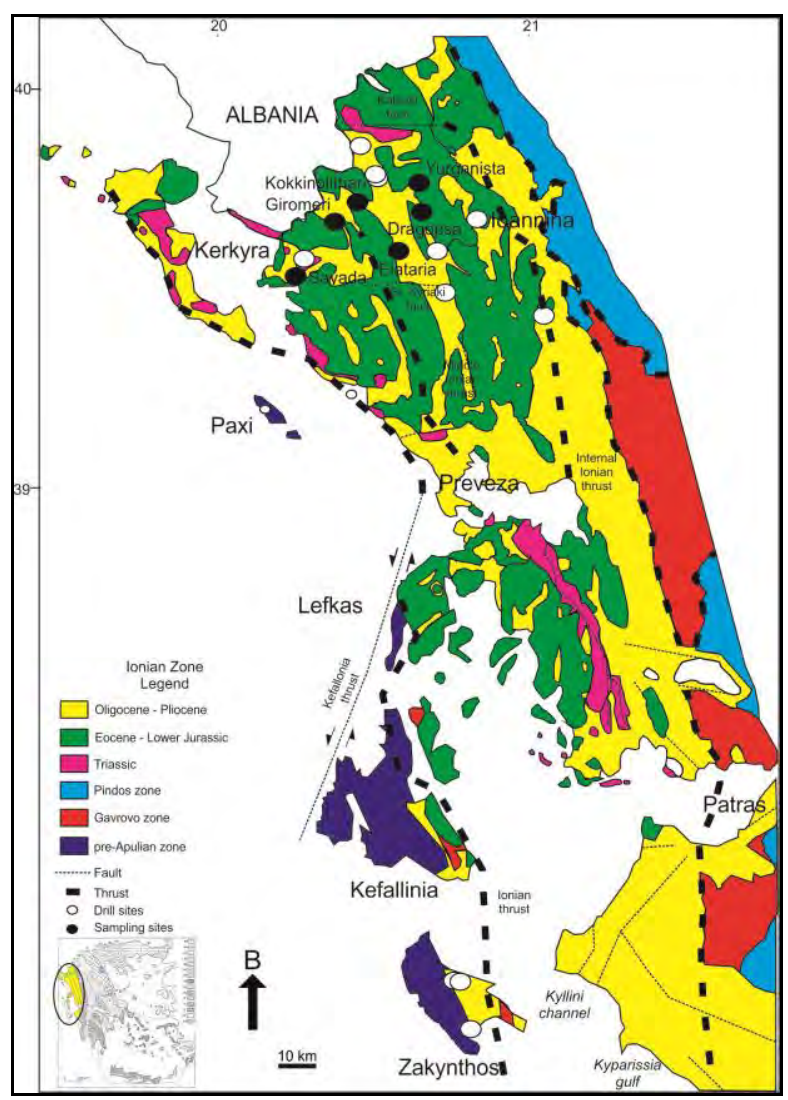

Figure 1 - Geological map of the Ionian Zone. Sampling sites are marked as black circles (after Zelilidis et al., 2003; Karakitsios and Rigakis, 2007; modified).

$\underline{\text { XLVII, No } 2 \text { - } 881}$ 
This study aims to provide with scientific data regarding the hydrocarbon potential of certain sedimentary formations of the Ionian Zone, by means of Organic Petrology techniques.

\section{Geological Setting}

Ionian Zone is part of the external Hellenides. During the early stages of formation, in Mesozoic times, the Ionian Zone was a submarine basin which separated the pre-Apulian platform in the west, from the Gavrovo Zone in the east (Figure 2). It is also divided in three sub zones, the External (pre-rift), the Axial (syn-rift) and the Internal one (post rift) that experienced significant differences into their sedimentation (Karakitsios, 2007).

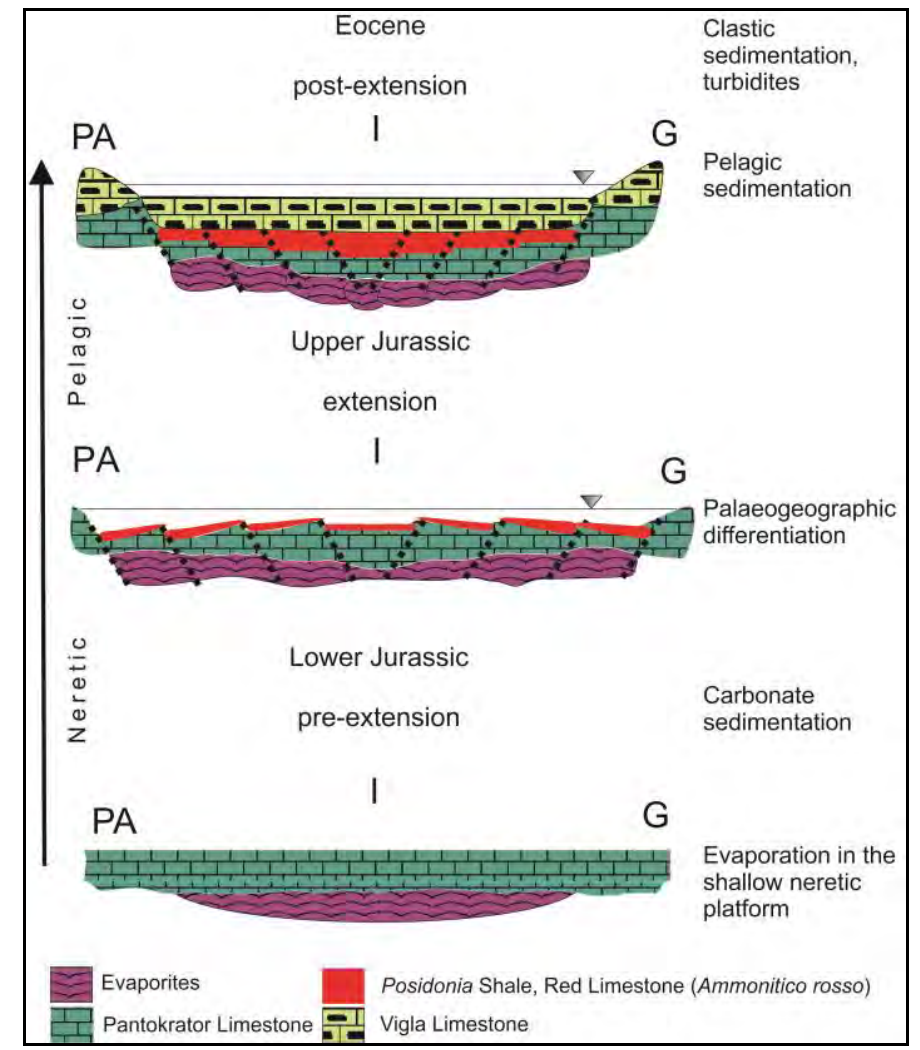

Figure 2 - Evolution of the Ionian Zone (modified after Jones and Robertson, 1991); (PA: Pre-Apulian platform, I: Ionian Zone, G: Gavrovo Zone).

From Lower Jurassic to Eocene, the sedimentation gradually changed from neretic to pelagic. In Early Triassic the excessive evaporation led to the deposition of evaporites that consistute the bedrock of the Ionian Basin (Figure 3). Later, in Lower Jurassic the sedimentation changed to carbonate-dominated (neretic) resulting in the deposition of the Pantokrator limestone. In Middle Jurassic the palaeogeographic evolution of the basin started with the deposition of the red limestone containing Ammonitico rosso in the shallow parts of the basin and the Posidonia shale in the deepest parts; the shale is distinguished into the Lower and the Upper Posidonia Beds corresponding to Toarcian and Callovian-Tithonian age, respectively.

In the transition from Jurassic to Cretaceous, the whole region was included in the foreland basin of Pindos Thrust and this affected the sedimentation, which gradually passed to pelagic with the deposition of the Vigla limestone. Turbidite deposits of Tertiary age overlie the Mesozoic carbonate rocks (Zelilidis et al., 2003; Karakitsios, 2007). All over the Ionian Zone, the formations containing considerable concentrations of organic matter are the following, from bottom to top: 
- The shale included in the Triassic evaporites

- The marls in the basis of Ammonitico-rosso limestone

- The Lower and Upper Posidonia Beds

- The Upper Siliceous formation of Vigla

- The turbidite sandstone (flysch)

The Lower (LPB) and Upper (UPB) Jurassic Posidonia Beds, the Cretaceous shale and the Miocene sandstone, are the formations on which this study focuses.

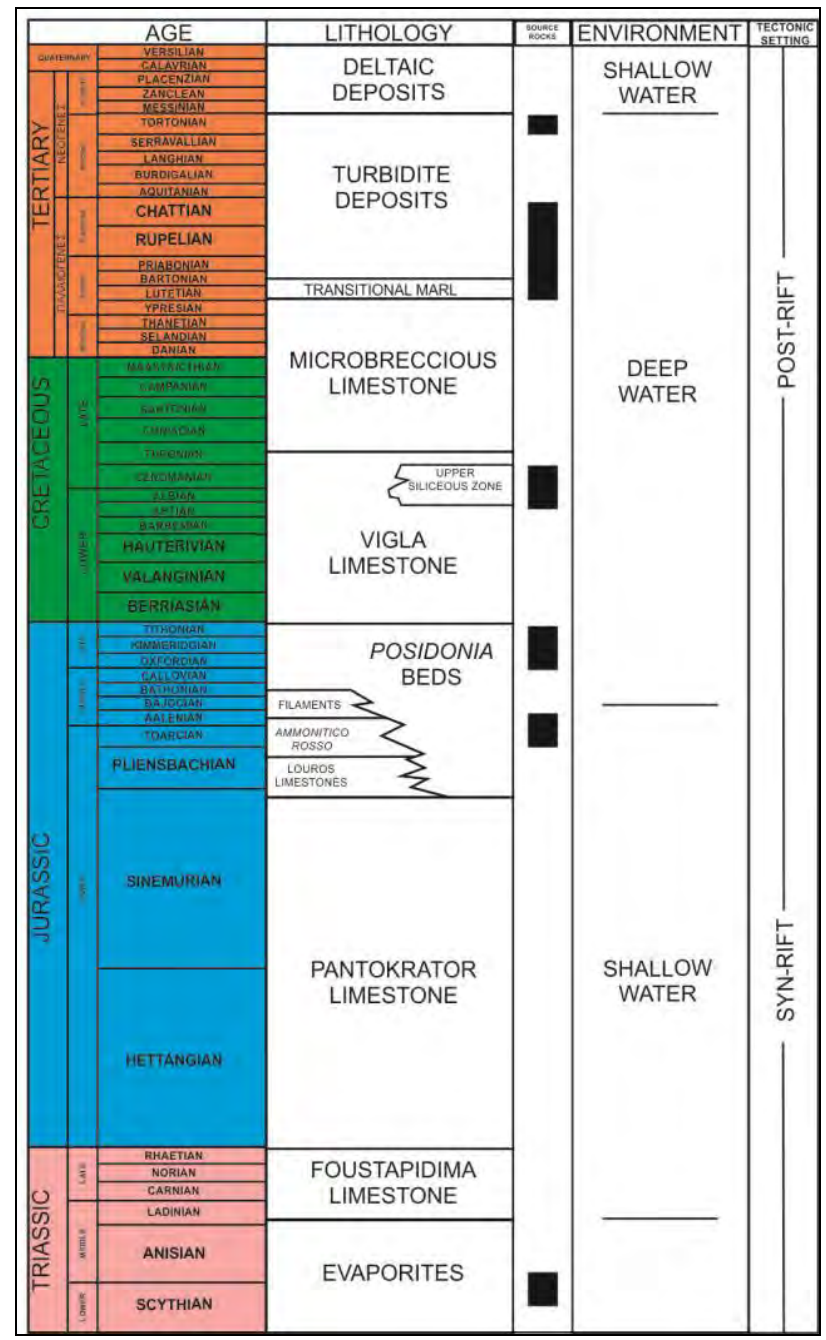

Figure 3 - Lithostratigraphical column of the Ionian Zone (Zelilidis et al., 2003, and references herein).

\section{Sampling}

Sampling took place in the areas of Elataria, Giromeri, Dragopsa, Kokkinolithari, Yurganista and Sayada in the region of Epirus (Figure 1). Eighteen samples in total, namely eleven from the Lower Jurassic Bituminous Shale strata, two from the Upper Jurassic Bituminous Shale strata, one from the Upper Cretaceous Upper Siliceous Vigla Formation and four from the Miocene Bituminous Sandstone, part of the Turbidite Formation, were picked up from outcrops (Table 1). 
Table 1 - Coordinates of the sampling sites based on World Geodetic System (WGS 84).

\begin{tabular}{|c|c|c|c|c|}
\hline Sample & Formation/Age & North $(\varphi)$ & East $(\lambda)$ & $\begin{array}{l}\text { Altitude } \\
\text { (m a.s.l.) }\end{array}$ \\
\hline Elataria (\#1) & $\begin{array}{l}\text { Medium to low thickness limestone } \\
\text { with chert nodules/Lower Jurassic }\end{array}$ & $39^{\circ} 32^{\prime} 23.50^{\prime \prime}$ & $20^{\circ} 32^{\prime} 20.5^{\prime \prime}$ & $680.1 \pm 6.9$ \\
\hline Elataria (\#2) & $\begin{array}{l}\text { Limestone with chert and } \\
\text { bituminous shale } \\
\text { alternations/Lower Jurassic }\end{array}$ & $39^{\circ} 32^{\prime} 18.70^{\prime \prime}$ & $20^{\circ} 30^{\prime} 14.4^{\prime \prime}$ & $644 \pm 43.5$ \\
\hline Giromeri (\#1) & $\begin{array}{l}\text { Shale poor in bitumens with chert } \\
\text { nodules/Lower Jurassic }\end{array}$ & $39^{\circ} 39^{\prime} 8.30^{\prime \prime}$ & $20^{\circ} 19^{\prime} 11.7^{\prime \prime}$ & $360 \pm 30$ \\
\hline Giromeri (\#2) & $\begin{array}{l}\text { Shale poor in bitumens with chert } \\
\text { alternations/Lower Jurassic }\end{array}$ & $39^{\circ} 39^{\prime} 1.20^{\prime \prime}$ & $20^{\circ} 19^{\prime} 35.3 ”$ & $360 \pm 30$ \\
\hline Dragopsa & $\begin{array}{l}\text { Turbidite sandstone with organic } \\
\text { matter/Miocene }\end{array}$ & $39^{\circ} 35^{\prime} 52.2^{\prime \prime}$ & $20^{\circ} 40^{\prime} 52.2^{\prime \prime}$ & $674.5 \pm 11$ \\
\hline Kokkinolithari & $\begin{array}{c}\text { Shale with chert alternations in } \\
\text { contact with limestone/Upper } \\
\text { Jurassic }\end{array}$ & 39³9’32.1” & $20^{\circ} 23^{\prime} 45.3^{\prime \prime}$ & $390 \pm 15$ \\
\hline Yurganista & Siliceous shale/Upper Cretaceous & $39^{\circ} 38^{\prime} 8.12^{\prime \prime}$ & $20^{\circ} 38^{\prime} 6.23^{\prime \prime}$ & $160 \pm 10$ \\
\hline Sayada & $\begin{array}{l}\text { Shale in contact with } \\
\text { mudstone/Upper Jurassic }\end{array}$ & $39^{\circ} 32^{\prime} 13.7^{\prime \prime}$ & $20^{\circ} 32^{\prime} 10.3^{\prime \prime}$ & $122.6 \pm 20.4$ \\
\hline
\end{tabular}

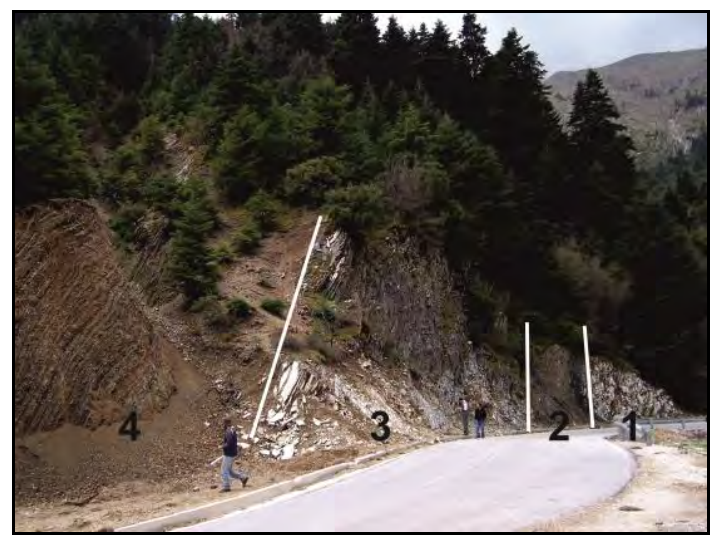

Figure 4 - The Triassic to Upper Jurassic sequence of the Ionian Zone at Elataria site:

1) Pantokrator limestone,

2) Lower Posidonia beds (LPB), 3) Intermediate limestone, 4) Upper Posidonia beds (UPB).

\section{Methodology}

The samples were treated firstly with an $\mathrm{HCl}(3 \mathrm{M})$, then with an $\mathrm{HF}(6 \mathrm{M})$ solution to remove the carbonates and the silicates, respectively. The concentrated residue was then mixed with a $\mathrm{ZnCl}_{2}$ solution $(1.6 \mathrm{~g} / \mathrm{ml})$ to apply density (or gravity) separation. The floating (organic-rich) substance was rinsed with deionized water and then freeze dried to remove moisture. The samples $(\varnothing<3$ $\mathrm{mm}$ ) were then mounted in epoxy resin. Polished blocks were prepared according to ISO 7404-2 (2009). Organic Petrography techniques including random vitrinite reflectance (Rr) measurement and maceral identification, under white incident light and blue-light excitation, were applied on the polished blocks. A Leica DMRX coal-petrography microscope with oil immersion lens, in a total magnification of $500 \mathrm{x}$, was used. The vitrinite reflectance measurement was conducted following ISO 7404-5 (2009). Theoretically, a hundred measurements should be taken on huminite/vitrinite in each polished block $(\varnothing 3 \mathrm{~cm})$, but a satisfactory mean average can also be achieved with less 
measurements depending on the organic matter content of the studied sample. The maceral classification was based on the ICCP $(1971,2001)$ \& Sýkorová et al. (2007) nomenclature.

Total Organic Carbon (TOC) content was determined by oxidizing the organic part (Jackson, 1958). This method is based on the oxidation of organic matter with a potassium dichromate/sulphuric acid solution and the calculation of organic carbon through the determination of dichromate excess in the solution. Thus, a wide range of organic forms except for the highly refractory fraction can be oxidized. The TOC values are calculated according to a formula based on the Walkey-Black method (Nelson and Sommers, 1996). Although the actual organic carbon of these samples may have been slightly underestimated, the results could be considered reliable. For verification purposes automatic elemental analysis (AEA) has been applied on several samples, using a CHNS (EAGER 200) Carlo Erba Elemental Analyser calibrated against CP1 material (ASTM D5373, 2004). Loss on Ignition (LOI at $550^{\circ} \mathrm{C}$ for $4 \mathrm{~h}$ ) was applied to estimate the organic matter content under ASTM (D 3174-2004) standards.

The mineralogical composition of the shale samples was determined applying X-ray diffraction on whole rock samples. A Bruker D8 X-ray diffractometer equipped with a LynxEye ${ }^{\circledR}$ detector was used for the mineralogical analyses. The mineral phases in the diffractograms were identified using EVA software.

\section{Results and Discussion}

It must be stated that the results should only be considered preliminary and adequate to qualify areas for further research, since they were obtained from outcrop samples, which have been affected by weathering; however, vitrinite reflectance can be considered a reliable measure of organic matter maturity even in the case of outcrop samples provided that the external highly weathered part is removed prior sampling. The outcrops are of a limited extent and contain chert intercalations, complicating laboratory tests. In more detail some of the outcrops sampled are as follows:

Elataria: Medium-bedded limestone with chert nodules. Thickness of the bituminous shale formation is approximately $1 \mathrm{~m}$, with alternations of non-bituminous shale. The limestone strata display medium to small thickness with chert intercalations thicker than $5 \mathrm{~m}$ (Figure 4, 5a).

Giromeri: Lower bituminous shale intercalated with limestone and chert nodules (Figure 5b).

Sayada: Upper shale mixed with silt material. The total thickness of the target formation is approximately $30 \mathrm{~cm}$ (Figure $5 \mathrm{c}$ ).

Yurganista: Poor in bitumens shale alternating with limestone (Figure 5d).
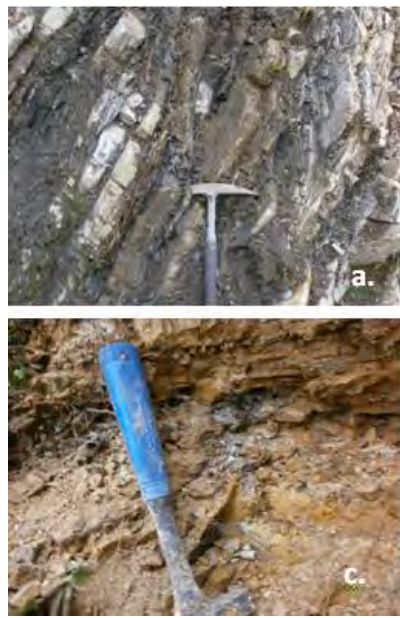
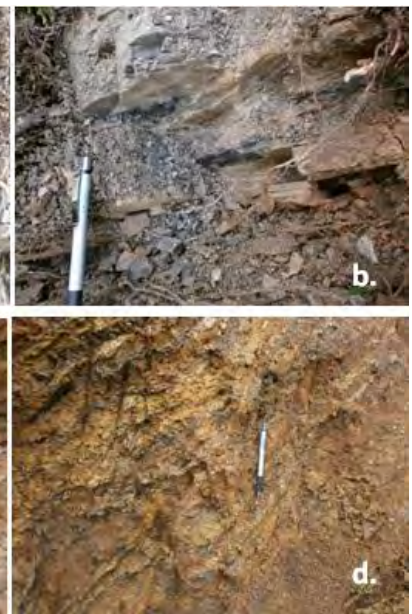

Figure 5 - The outcrops at the sampling sites: $(a, b)$ Lower Posidonia Shale at Elataria and Giromeri, respectively, (c) Upper Posidonia Shale at Sayada, (d) Upper Siliceous Vigla Formation at Yurganista.

$\underline{\text { XLVII, No } 2-885}$ 
The Elataria and (to a lesser extent) the Giromeri samples contain significant quantities of TOC reaching up to $4.75 \%$. All other samples display very low contents.

The $\mathrm{Rr}$ of the Lower Shale in the studied area of Elataria ranges between 0.5 and $0.7 \%$, corresponding to a maturation stage within the oil window (Taylor et al., 1998). The liquid hydrocarbon generation commences at a $\operatorname{Rr} 0.5-0.6 \%$. Nevertheless the important build up begins between 0.6 and $0.85 \%$ and cannot exceed $1.8 \%$ for kerogen type III source rocks (Petersen, 2002). The organic matter in the rest of the samples appears rather immature displaying $\mathrm{Rr}<$ $0.5 \%$, i.e. out of the oil window, and in some cases (e.g. at Kokkinolithari; $0.15 \% \mathrm{Rr}$ ) equivalent to recent organic matter.

Amorphous organic matter (particulate organic components that appear structureless at the scale of light microscopy; Mendonça Filho et al., 2011) was dominant in all the studied samples. Macerals of the vitrinite, liptinite and inertinite groups are also present. The liptinite group includes typical macerals of kerogen types I and II. Kerogen type I derives from green and blue algae that sustain in reductive environments whereas type II originates from natural wax, lipids and plant resins. In general, the samples are poor in vitrinite. The dispersed organic matter in type I and II rocks is capable of yielding liquid and gas hydrocarbons (Tissot and Welte, 1984). Figure 6 displays some abundant types of organic matter contained in the studied samples.

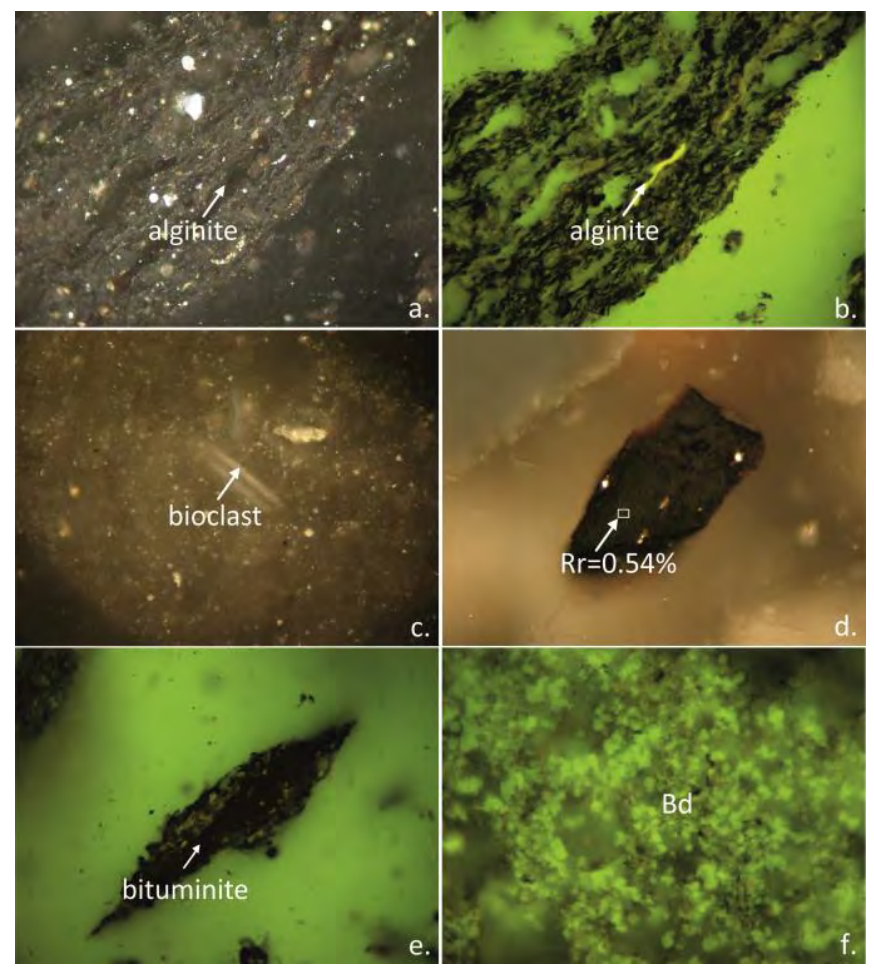

Figure 6 - Photomicrographs taken under oil-immersion, magnification 500X, photograph width is $265 \mu \mathrm{m}$ : a, b. Alginite under white light (a) and blue light excitation (b), c. Bioclast, d. Vitrinite under white incident light, e. Bituminite under blue light excitation, f. Bitumen drops under blue light excitation.

Table 2 displays the results of the detailed characterization of the samples. The Elataria samples display the highest TOC and LOI values, whereas the reflectance falls close $(0.49 \%)$ or within $(0.68 \%)$ the oil window. The Dragopsa sandstone samples contain two different varieties of macerals appropriate for reflectance measurements, one displaying $\mathrm{Rr} \sim 0.29 \%$ (huminite) and another one $\sim 0.90 \%$ (vitrinite). According to Avramidis et al. (2002) the submarine fans have the potential to yield hydrocarbons. This is in agreement with the high vitrinite content of the Dragopsa sample, typical for kerogen type III being gas-prone. 
Table 2 - Total organic carbon and elemental carbon contents, loss on ignition and mean random vitrinite reflectance (*: sandstone sample, **: no vitrinite, L: Liptinite, V: Vitrinite, I: Inertinite; Characterization after Tyson, 1989, 1995).

\begin{tabular}{|c|c|c|c|c|c|c|}
\hline Sample & $\begin{array}{l}\text { TOC } \\
(\%)\end{array}$ & $\begin{array}{c}\mathrm{C} \\
(\%)\end{array}$ & $\begin{array}{l}\text { LOI } \\
(\%)\end{array}$ & $\begin{array}{l}\text { Mean } \\
\text { Rr\% }\end{array}$ & $\begin{array}{l}\text { Maceral } \\
\text { groups }\end{array}$ & Characterization \\
\hline Elataria $(\# 1)$ & 2.87 & & 8.79 & 0.49 & \multirow{4}{*}{$\mathrm{L}>\mathrm{V}>\mathrm{I}$} & Excellent source potential \\
\hline Elataria $(\# 2)$ & 4.75 & 3.69 & 11.38 & 0.68 & & $\begin{array}{l}\text { Modal range for marine } \\
\text { 'black shale' source rocks }\end{array}$ \\
\hline Giromeri (\#1) & 0.92 & \multirow[b]{2}{*}{0.39} & 2.44 & 0.40 & & 'Fair' source potential \\
\hline Giromeri (\#2) & 0.25 & & 3.02 & 0.31 & & $\begin{array}{l}\text { 'Poor' source potential } \\
\text { Deep-sea facies }\end{array}$ \\
\hline Sayada & 0.46 & 0.59 & 3.65 & $* *$ & \multirow{3}{*}{$\mathrm{I}>\mathrm{V}>\mathrm{L}$} & 'Poor' source potential \\
\hline Kokkinolithari & 0.30 & 0.16 & 0.79 & 0.15 & & 'Poor' source potential \\
\hline Yurganista & 0.28 & 0.31 & 4.47 & 0.26 & & $\begin{array}{l}\text { 'Poor' source potential } \\
\text { Deep-sea facies }\end{array}$ \\
\hline Dragopsa* & 0.34 & 1.43 & 7.31 & $0.29 / 0.90$ & $\mathrm{~V}>\mathrm{I}>\mathrm{L}$ & $\begin{array}{l}\text { Industry limit for } \\
\text { carbonate source rocks }\end{array}$ \\
\hline
\end{tabular}

The qualitative mineralogical composition of the studied samples is presented in Table 3. Elataria \#1 \& 2 and Giromeri \#1 \& 2 samples are merged due to similar mineralogical composition. Quartz is the major component. Chlorite, albite, calcite, chrysotile and montmorillonite were also identified. The mineralogical composition is used here as a supplementary tool, in order to better interpret the results from TOC determination and LOI. Calcite is present at low concentration in four samples and lacks from the rest. Thus total carbon values, especially for both Elataria samples, can be considered to be equal to TOC. Additionally, the presence of hydroxyl-bearing minerals (chrysotile, chlorite, montmorillonite) indicates that LOI overestimates the actual organic matter content. For this reason the ratio between TOC and LOI is higher than 2 being typical for sedimentary organic matter (Schumacher, 2002).

Table 3 - Mineralogical composition of the samples (M: Major, m: Minor, t: Trace)

\begin{tabular}{|l|c|c|c|c|c|c|c|}
\hline \multicolumn{1}{|c|}{ Sample } & Quartz & Chlorite & Albite & Calcite & K-Feldspar & Chrysotile & Clay \\
\hline Elataria & $\mathrm{M}$ & & & $\mathrm{t}$ & & & $\mathrm{m}$ \\
\hline Giromeri & $\mathrm{M}$ & & & $\mathrm{m}$ & & & $\mathrm{m}$ \\
\hline Dragopsa & $\mathrm{M}$ & $\mathrm{m}$ & $\mathrm{m}$ & $\mathrm{M}$ & $\mathrm{t}$ & $\mathrm{m}$ & \\
\hline Kokkinolithari & $\mathrm{M}$ & & & & & & \\
\hline Yurganista & $\mathrm{M}$ & & & & & & $\mathrm{m}$ \\
\hline Sayada & $\mathrm{M}$ & $\mathrm{m}$ & $\mathrm{m}$ & $\mathrm{m}$ & & & $\mathrm{m}$ \\
\hline
\end{tabular}

In order to evaluate the source-rock potential, the TOC and Rr values (Table 2) were plotted on the diagram of Figure 7. Only the Elataria samples are promising to have acted as petroleum sourcerocks. All other samples display a relatively immature stage of diagenesis and despite the adequate organic matter type and content (e.g. the Giromeri samples) cannot be characterized as good source rocks. 


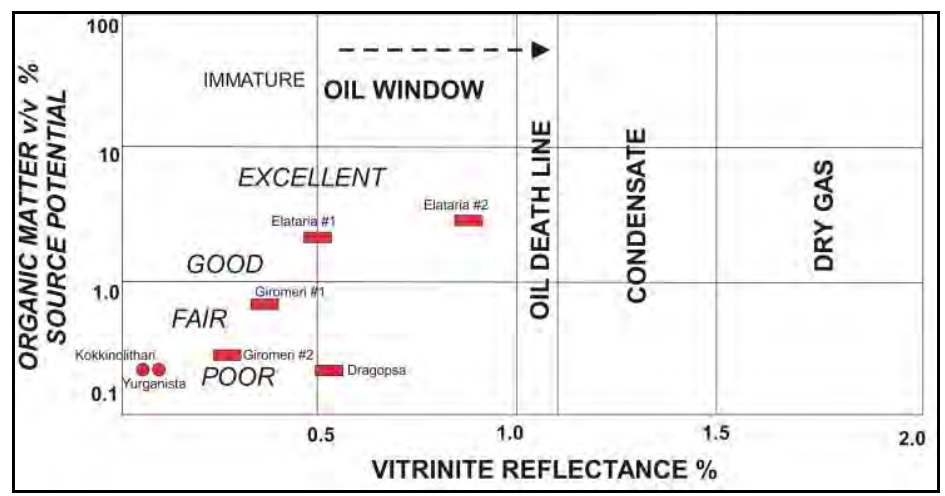

Figure 7 - Source potential to maturation scheme (after Cook, 2011).

\section{Conclusion}

The Lower Jurassic Posidonia shale (e.g. at Elataria sampling site) seems to have the potential to generate hydrocarbons. In general, the abundance of liptinite group macerals (alginite, sporinite) is typical for kerogen types I and II being highly oil prone. The vitrinite reflectance values in addition to the high TOC content set the samples within the oil window. Of course, detailed and higher resolution sampling focusing on the Lower Posidonia Shale, as well as organic petrography analyses coupled with Rock-Eval pyrolysis should be carried out in order to accurately determine its quality as petroleum source rocks.

\section{Acknowledgements}

The authors would like to thank Dr. Konstantina Katsanou for her field work assistance, as well as Dr. Paraskevi Lamprpoulou for the X-Ray Diffraction analyses, Mr. Panagiotis Mpalasis (all from Dept. of Geology, Univ. of Patras) for polishing the blocks. Mr. Dimitrios Vachliotis (Lab of Instrumental Analyses, Faculty of Sciences, Univ. of Patras) is thanked for the elementary analyses.

\section{References}

American Society for Testing and Materials (ASTM) D3174, 2004. Standard method for ash in the analysis sample of coal and coke from coal. In: 2004 Annual Book of ASTM Standards, Gaseous Fuels, Coal and Coke, American Society for Testing and Materials, PA, Philadelphia, Vol. 05.06, pp. 322-326.

American Society for Testing and Materials (ASTM) D5373, 2004. Standard test methods for instrumental determination of carbon, hydrogen and nitrogen in laboratory samples of coal and coke. In: 2004 Annual Book of ASTM Standards, Gaseous Fuels; Coal and Coke, vol. 05.06., ASTM, Philadelphia, PA, pp. 504-507.

Avramidis P. and Zelilidis A. 2001. The nature of deep-marine sedimentation and palaeocurrent trends as an evidence of Pindos foreland basin fill conditions, Episodes, 24(4), 252-256.

Avramidis P., Zelilidis A., Vakalas I. and Kontopoulos N. 2002. Interactions between tectonic activity and eustatic sea-level changes in the Pindos and Mesohellenic basins, NW Greece: Basin evolution and hydrocarbon potential, J. Petrol. Geol., 25(1), 53-82.

British Petroleum Company Limited (BP) 1971. The geological results of petroleum exploration in western Greece, Inst. Geol. Subs. Res., Athens, 10, 1-73.

Cook A. 2011. The Role of Organic Petrology in Oil and Gas Exploration, ICCP Training Course on Dispersed Organic Matter, pp. 119-126.

Institut de Géologie et Recherches du Sous-Sol, Institut Français du Pétrole (IGRS-IFP), 1966. Étude Géologique de l'Épire, Ministére de l'Industrie, Athénes, 306 pp. 
International Committee for Coal Petrology (ICCP) 1971, International Handbook of Coal Petrography, $1^{\text {st }}$ suppl. to $2^{\text {nd }}$ edn. Centre National de la Recherche Scientifique, Paris.

International Committee for Coal and Organic Petrology (ICCP) 2001. The new inertinite classification (ICCP System 1994), Fuel, 80, 459-471.

International Organization for Standardization (ISO) 7404-2 2009. Methods for the Petrographic Analysis of Coals - Part 2: Methods of Preparing Coal Samples, International Organization for Standardization, Geneva, Switzerland, $12 \mathrm{pp}$.

International Organization for Standardization (ISO) 7404-5, 2009. Methods for the Petrographic Analysis of Coal - Part 5: Methods of Determining Microscopically the Reflectance of Vitrinite, International Organization for Standardization, Geneva, Switzerland, $14 \mathrm{pp}$.

Jackson M.L. 1958. Soil Chemical Analysis, Prentice-Hall Inc., Englewood Cliffs, NJ.

Jenkins D.A.L. 1972. Structural development of western Greece, AAPG Bulletin, 56, 128-149.

Jones G. and Robertson A.H.F. 1991. Tectonostratigraphy and evolution of the Mesozoic Pindos ophiolite and related units, northwestern Greece, J. Geol. Soc.of London, 148, 267-288.

Karakitsios V. 2003. Evolution and Petroleum Potential of the Ionian Basin (Northwest Greece), AAPG International Conference, (September 21-24, Barcelona, Spain), 7 pp.

Karakitsios V. 2007. Studying the carbonates from Triassic to Eocene in the Ionian Zone, $25^{\text {th }}$ IAS Meeting of Sedimentology, 2007, Patras-Greece, Field Trips Guide Book, p.123-142.

Karakitsios V. and Rigakis N. 1996. New oil source rocks in Greek Ionian basin, Oil and Gas J., $12,56-59$.

Karakitsios V. and Rigakis N. 2007. Evolution and petroleum potential of western Greece, $J$. Petrol. Geol., 30(3), 197-218.

Kokkinou E., Kamberis E., Vafidis A., Monopolis D., Ananiadis, G. and Zelilidis A. 2005. Deep seismic reflection data from offshore western Greece: a new crystal model for the Ionian Sea, J. Petrol. Geol., 28, 81-98.

Mendonça Filho J.G., Menezes T.R. and Mendonça J.O. 2011. Organic Composition (Palynofacies Analysis), ICCP Training Course on Dispersed Organic Matter, pp. 33-81.

Nelson D.W. and Sommers L.E. 1996. Total carbon, organic carbon and organic matter. In: Methods of soil analysis part3: Chemical methods, Sparks D.L., Page A.L., Helmke P.A., Loeppert R.H., Soluanpour P.N., Tabatabai M.A., Johnston C.T., Sumner M.E. (Eds), Soil Science Society of America, Inc. and American Society of Agronomy, Inc., Madison, Wisconsin, USA. pp. 961-1010.

Petersen H.I. 2002. A re-consideration of the 'Oil Window' for humic coals and kerogen type III source rocks, J. Petrol. Geol., 25(4), 407-432.

Rigakis N. and Karakitsios V. 1998. The source rock horizons of the Ionian Basin (NW Greece), Marine Petrol. Geol., 15, 593-617.

Schumacher B.A. 2002. Methods for the Determination of Total Organic Carbon (TOC) in Soils and Sediments, United States Environmental Protection Agency, NCEA-C-1282, 23 pp.

Sýkorová I., Pickel W., Christanis K., Wolf M., Taylor G.H. and Flores D. 2005. Classification of huminite - ICCP System 1994, Int. J. Coal Geol., 62, 85-106.

Taylor G.H., Teichmüller M., Davis A., Diessel C.F.K., Littke R. and Robert P. 1998. Organic Petrology, Gebrüder Borntraeger, Berlin, Stuttgart, 704 pp.

Tissot B.P. and Welte D.H. 1984. Petroleum Formation and Occurrence, 699 pp.

Tyson R.V. 1989. Late Jurassic palynofacies trends, Piper and Kimmmeridge Clay Formations, UK onshore and northern North Sea. In: Northwest European Micropalaeontology and Palynology, Batter, D.J., Keen, M.C. (Eds), The British Micropalaeontological Society Series, Ellis Horwood, Chichester, pp. 135-172.

Tyson R.V. 1995. Sedimentary Organic Matter. Organic facies and palynofacies, Chapman and Hall, London, $615 \mathrm{pp}$.

Zelilidis A., Piper D.J.W., Vakalas I., Avramidis P. and Getsos K. 2003. Oil and gas plays in Albania: Do equivalent plays exist in Greece?, J. Petrol. Geol., 26(1), 29-48. 